\title{
DESEKULERISASI ULAMA;
}

Makna Ulama Menurut Nurcholish Madjid

\section{Oleh Imam Hanafi dan Sofiandi}

\begin{abstract}
Abstrak: Ulama menduduki posisi penting dalam masyarakat Islam. Ulama tidak hanya sebagai figur ilmuan yang menguasai dan memahami ajaranajaran agama, tetapi juga sebagai penggerak, motivator dan dinamisator masyarakat ke arah pengembangan dan pembangunan umat. Perilaku ulama selalu menjadi teladan dan panutan. Ucapan ulama selalu menjadi pegangan dan pedoman. Ulama dalam pandangan Nurcholish Madjid adalah menjaga akhlaq masyarakat. Pengetahuan dan pendalaman tentang ajaran agama yang dimilikinya memungkinkan para ulama bertindak selaku kekuatan moral. Yang kedua adalah mereka yang memahami dengan penuh penghayatan gejala-gejala alam sekitarnya seperti hujan (meteorologi), tetumbuhan (flora), fenomena geologis gunung-gunung (mineralogi), gejala kemanusiaan (ilmu-ilmu sosial), dan binatang-binatang (fauna) dengan berbagai variasi dan kompleksitasnya. Hal ini berarti bahwa seorang ulama tidak memisahkan ilmu pengetahuan dengan nilainilai moral religius. Antara ilmu dan etika, kesemuanya adalah satu kesatuan mutlak. Ilmu dan aktivitas keilmuan merupkan manifestasi dari pengabdian manusia kepada Tuhan.
\end{abstract}

Kata Kunci: Ulama, Desekulerisasi, Islam 


\section{Desekulerisasi Ulama; \\ Makna Ulama Menurut Nurcholish Madjid}

\section{Oleh Imam Hanafi dan Sofiandi}

\section{Pendahuluan}

Istilah sekulerisasi pernah menjadi salah satu isu paling populer yang melekat pada diri Prof. Dr. Nurrcholish Madjid (selanjutnya kita sebut saja dengan Cak Nur). ${ }^{1}$ Munculnya istilah ini, digunakan Cak Nur pada pertemuan silaturahim antara para aktivis, anggota, dan keluarga dari empat organisasi Islam, yaitu Persami, HMI, GPI, dan PII yang diselenggarakan oleh PII Cabang Jakarta, di Jakarta 3 Januari 1970. Pada saat itu, Cak Nur menulis artikel yang berjudul, "Keharusan Pembaruan Pemikiran Islam dan Masalah Integrasi Umat". ${ }^{2}$ Menurut Budhy Munawar-Rahman, ide sekularisasi pada mulanya dimaksudkan sebagai "devaluasi" atau "demitologisasi" atas apa saja yang bertentangan dengan ide tawhîd, yaitu pandangan yang paling asasi dalam Islam. ${ }^{3}$ Selanjutnya ia menjelaskan :

Jargon Cak Nur yang terkenal, "Islam, Yes, Partai Islam, No”, misalnya mau mengatakan, partai Islam itu (sekarang) bukan hal yang esensial, dan (sama sekali) tidak berhubungan dengan esensi keislaman. Itulah makna "sekularisasi", yaitu mengembalikan mana yang sakral, sebagai sakral, dan yang profan, sebagai profan.

${ }^{1}$ Istilah sekulerisasi atau sekulerisme sebenarnya sudah muncul sejak tahun 1846 oleh George Holyoake, seorang penulis dari Inggris. LIhat Budhy Munawar-Rahman, Argumen Islam untuk Sekularisme; Islam Progresif dan Perkembangan Diskursusnya, (Jakarta : Grasindo, 2010), h. 3.

2 Budhy Munawar-Rachman, Membaca Nurcholish Madjid Islam dan Pluralisme, Edisi Digital, (Jakarta : Democracy Project, 2011), h. 10 - 11.

${ }^{3}$ Ibid, h. 15 - 16. 
Politik Islam yang tadinya dianggap "sakral", yaitu merupakan bagian dari perjuangan Islam, sekarang "didesakralisasi, yang kemudian menimbulkan perdebatan besar mengenai sekularisasi-sekularisme. ${ }^{4}$

Lebih lanjut, ia menjelaskan;

Penggunaan kata sekularisasi dalam sosiologi mengandung arti pembebasan, yaitu pembebasan dari sikap penyucian yang tidak pada tempatnya. Karena itu ia mengandung makna desakralisasi, yaitu pencopotan ketabuan dan kesakralan dari objek-objek yang semestinya tidak tabu dan tidak sakral. Jika diproyeksikan kepada situasi modern Islam sekarang, maka itu akan mengambil bentuk pemberantasan bid'ah, khurafat, dan praktik syirik lainnya ... (maka) sekularisasi ... adalah konsekuensi dari tawhîd." Istilah "sekularisasi" inilah yang akhirnya menjadi pangkal kehe-bohan. Karena istilah (yang tidak menguntungkan ini), Cak Nur pun diberi cap "kaum sekularis", karena dianggap mempromosikan sekularisme, padahal jelasjelas ia mengatakan, "Sekularisasi tidaklah dimaksudkan sebagai penerapan sekularisme, dan mengubah kaum Muslim sebagai sekularis."

Istilah Sekularisasi itu sendiri berakar dari kata Sekuler yang berasal dari bahasa latin Seaculum artinya abad (age, century), yang mengandung arti bersifat dunia, atau berkenaan dengan kehidupan dunia sekarang. Dalam bahasa Inggris kata secular berarti hal yang bersifat duniawi, fana, temporal, tidak bersifat spritual, abadi dan sakral serta kehidupan di luar biara. ${ }^{6}$ Saya sengaja menggunakan kata desekularisasi di dalam tulisan ini, bukan bermaksud men-"desekular"-kan gagasan Cak

${ }^{4}$ Ibid,h. 16

${ }^{5}$ Ibid, h. 30

${ }^{6}$ Juhaya S. Praja, Aliran-Aliran Filsafat dan Etika, (Cet. I; Bogor: Kencana, 2003), h. 188. Lihat pula Harun Nasotion, Islam Rasional : Gagasan dan Pemikiran, (Cet. V; Bandung: Mizan, 1998), h. 188 
Nur tentang sekularisasi di atas. Pada substansinya istilah desekularisasi memiliki makna yang sama dengan integrasi, dedualisme, dediferensiasi dan semua kata yang memiliki arti penyatuan atau rujuk kembali. Kalau dikaitkan dengan problema keilmuan, maka desekularisasi keilmuan berarti penyatuan kembali agama dengan ilmu pengetahuan (sains). ${ }^{?}$

Salah satu sosok ulama yang "diidealkan" oleh Cak Nur, menurut saya adalah ketika beliau menggambarkan idealisme para Tokoh Masyumi:

.....Mereka adalah orang-orang yang dengan sangat berhasil telah mengkombinasikan unsur-unsur terpenting dari dua pandangan hidup: Islam dan westernisasi, atau dalam ungkapan yang lebih baik, Islam dan modernisasi. Dari Islam, mereka mempelajari kesalehan dan ketakwaan; dan dari Barat, mereka telah berhasil mengapresiasi gagasangagasan seperti demokrasi, hak-hak asasi, dan aturanaturan hukum. Secara umum, mereka telah belajar mengenai hal-hal tersebut secara lebih baik daripada orang-orang Indonesia lainnya. Mereka adalah orangorang yang akan dicatat sejarah sebagai orang-orang yang penuh kebijaksanaan dan jujur di Indonesia, dan saya berpendapat bahwa etika mereka adalah sangat dibutuhkan di dalam membangun kebijaksanaan ekonomi.... ${ }^{8}$

Pernyataan tersebut mempertegas keinginan Cak Nur dalam memahami ulama', yaitu mampu mengkombinasikan antara Islam sebaga

7 Salah satu bentuk contoh dari usaha ini adalah adanya kecenrungan di kalangan pembuat kebijakan pendidikan tinggi Islam untuk mengembalikan semangat kajian Islam yang lebih komprehensif lagi; disiplin keilmuan yang dicakup IAIN tidak melulu meliputi disiplin ilmu agama semata, namun juga ilmu-ilmu umum yang bernuansa ke-Islaman, seperti psikologi, komunikasi, sosiologi, antropologi, dan lain sebagainya. Ke depan, IAIN akan dikembangkan dalam bentuk Universitas Islam Negeri (UIN) yang membawahi bidang kajian ke-Islaman dan ilmu-ilmu sekuler.

${ }^{8}$ Budhy Munawar-rachman, Membaca Nurcholish Madjid Islam dan Pluralisme, Edisi Digital, (Jakarta : Democracy Project, 2011), hlm. 14 
etika dan cara pandang hidupnya, sementara modentitas sebagai dasar dalam memahami nilai-nilai kemanusian dan demokrasi. Dua Satu sisi ia mampu memaknai hidup dengan agamanya, keislamanya dengan segala bentuk teori dan kefasihan keagamaanaannya, sekaligus ditunjang dengan kemampuan terhadap teori-teori Barat atau moderen tentang kemanusiaan. Artinya, ada upaya Cak Nur, untuk "menyatukan" dua kutub - Islam dan Barat- dalam pribadi seorang Ulama.

\section{Problem ”Kekuasaan” Ulama}

Secara kebahasaan, kata ulama berasal dari kata kata alim, yang berarti orang yang berilmu atau yang berpengetahuan. Jika kata alim disempurnakan dengan isim fail (kata kerja dari kata alima), maka ia berarti telah berilmu atau telah mengetahui. Oleh sebab itu, Ulama berarti orang-orang yang berilmu atau orang-orang yang mengetahui. ${ }^{9}$

Secara lebih spesifik, Sayyid Quttub menjelaskan makna Ulama adalah orang-orang yang memikirkan dan memahami kitab al-Qur'an. ${ }^{10}$ Sementara Hasan al-Bashri menyatakan bahwa ulama adalah orang yang takut kepada Allah yang tidak nampak, dan senang kepada yang disenangi Allah, serta meninggalkan apa-apa yang dibenci oleh Allah. ${ }^{11}$ Dawam Rahardjo memberikan indikasi bahwa ulama memiliki ciri-ciri sebagai berikut; 1). Sebagai pengemban tradisi agama; 2). Orang yang paham secara hukum Islam; dan 3). Sebagai pelaksana hukum fiqih. ${ }^{12}$

Sehingga secara sosologis, penyebutan term keulamaan pada diri seseorang bukan melalui suatu proses formal, tetapi melalui pengakuan setelah melalui proses panjang dalam masyarakat itu sendiri dimana unsur-unsur keulamaan pada seseorang berupa integritas, kualitas keilmuan dan kredibilitas kesalehan moral dan tanggung jawab sosialnya dibuktikan. Keulamaan seseorang tidak akan termanifestasi secara riil jika

9 Mahmud Yunus, Kamus Arab-Indonesia, (Jakarta : Yayasan Penyelenggara Penerjemah Penafsir Al-Qur;an, 1973), h. 278.

${ }^{10}$ Sayyid Qutb. Fi Dzilalil Qur'an, (Beirut : Ihyan al-Turats al-Arabi, 1967), h. 698.

${ }^{11}$ Dikutip dari Al-Maraghi, Tafsir Al-Maraghi, Jilid VIII, (Beirut : Dar al-Fikr, 1974), h. 127 
tidak dibarengi dengan penampakan sifat-sifat pribadi yang pantas mereka miliki. $^{13}$

Dalam konteks Indonesia, ulama juga mempunyai sebutan yang berbeda pada setiap daerah seperti; Kyai (Jawa), ${ }^{14}$ Ajengan (Sunda), Tengku (Aceh), Syeikh (Sumatera Utara/Tapanuli) dan Tuan Guru (Nusa Tenggara dan Kalimantan).

Kehadiran ulama di Indonesia, beriring serta dengan proses penyebaran Islam itu sendiri. Transformasi nilai keagamaan secara massif dilakukan oleh para ulama ini, terutama di lembaga-lembaga pendidikan tradisional seperti pesantren. ${ }^{15}$ Lebih-lebih telah terbukti secara historis bahwa secara ekstensif, terdapat keterkaitan antara umat Islam di Indonesia dengan para 'ulama di Jazirah Arab seperti Mekah dan Madinah, belakangan Kairo. ${ }^{16}$ Hubungan keagamaan yang sudah sedemikian established di antara kedua komunitas Muslim ini pada gilirannya menciptakan sebuah iklim intellectual exchanges yang relatif dinamis dan dialektis antar mereka. Daratan Jazirah Arab selanjutnya dikenal sebagai oase subur yang memproduksi karya-karya intelektual keIslaman yang dikonsumsi oleh masyarakat Muslim di Indonesia. Proses transmisi epistemologis ini berlangsung melalui beragam cara, baik langsung maupun tidak langsung, mulai dari diseminasi hasil karya-karya intelektual 'ulama Timur Tengah di banyak lembaga pesantren maupun

${ }^{13}$ M. Dawam Rahardjo, Intelektual Integensia dan Perilaku Politik Bangsa Risalah Cendikiawan Muslim, (Bandung : Mizan, 1993), h. 196

${ }^{14}$ Menurut Zamakhsyari Dhofier, istilah Kyai dalam masyarakat jawa tidak diperuntukkan pada orang yang ahli dalam agama Islam an sich, melainkan juga sebagai gelar kehormatan bagi barang-barang yang dianggap keramat. Misalnya Kyai Garuda Kencana, dipakai untuk sebutan Kereta Emasa yang ada di Keraton Yogyakarta. Juga gelar kehormatan untuk orang-orang tua pada umumnya. Lihat Zamakhsyari Dhofier, Tradisi Pesantren, (Jakarta : LP3ES, 1985), h. 55. Lihat juga penjelasan Manfred Ziemek dalam bukunya, Pesantren dalam Perubahan Sosial, (Jakarta: P3M, 1986), h. 131

${ }^{15}$ M. Atho Mudzhar, "In the Making of Islamic Studies in Indonesia (In Search for a Qiblah)," makalah disampaikan dalam seminar internasional Islam in Indonesia: Intellectualization and Social Transformation, di Jakarta 23-24 November 2000, h. 1.

${ }^{16}$ Azyumardi Azra, Jaringan Intelektual Ulama Nusantara, (Bandung: Mizan, 1994). 
pengiriman generasi muda Islam yang ingin memperdalam ilmu agamanya ke negara-negara di wilayah ini. ${ }^{17}$

Namun demikian, proses transmisi tersebut, masih dikeluhkan oleh Cak Nur ketika berada di masjid KBRI Islamabad. Di sana Cak Nur mengeluhkan bahwa ulama sekarang tidak berani menembus batas keilmuan yang pernah dicapai ulama-ulama terdahulu. ${ }^{18}$ Para Ulama tersebut cenderung mengembangkan metode hafalan terhadap beberapa hal yang sudah terdapat dalam teks-teks karya para pemikir sebelumnya. Persoalannya adalah ketika tradisi tersebut berlangsung secara turuntemurun dari generasi ke generasi. Sehingga tidak aneh jika kemudian kita sulit menemukan seorang ulama yang berhasil menelurkan magnum opus (karya agung) yang mampu menandingi ulama-ulama besar sekaliber imam al-Bukhari, Muslim, Ibn Taimiyyah, ataupun seperti seorang pemikir-filsuf Muhammad Iqbal dari Pakistan.

Keluhan Cak Nur di atas, barangkali berangkat dari kegagalan pendidikan ${ }^{19}$ agama Islam yang terlalu menitikberatkan pada hal-hal yang

${ }^{17}$ Mona Abaza, Indonesian Students in Cairo, (Paris: EHESS, 1994).

${ }^{18}$ Ahmad Fatoni, "Mendongkrak Pamor Pendidikan Islam" Sriwijaya Pos, Rabu, 05 Mei 2004.

${ }^{19}$ Menurut Nurcholis Majid, membicarakan pendidikan melibatkan banyak hal yang harus direnungkan, sebab pendidikan meliputi keseluruhan tingkah laku manusia yang dilakukan demi memperoleh kesinambungan, pertahanan dan pengingkatan hidup. Dalam bahasa agama, demi memperoleh ridla atau perkenan Allah. Lihat Pengantarnya "Pendidikan, Langkah Strategis Mempersiapkan SDM Berkualitas" dalam Indra Djati, Menuju Masyarakat Belajar Menggagas Paradigma Pendidikan, (Jakarta: Paramadina, 2001), hlm. xi. Demikian pula, Zakiah Darajat, seperti dikutip Jalaluddin, menulis bahwa pendidikan merupakan bagian yang tidak dapat dipisahkan dari hidup dan kehidupan manusia. John Dewey menyatakan, bahwa pendidikan sebagai salah satu kebutuhan, fungsi sosial, sebagai bimbingan, sarana pertumbuhan yang mempersiapkan dan membukakan serta membentuk disiplin hidup. Lihat. Jalaluddin, Teologi Pendidikan, (Jakarta: PT. Raja Grafindo Persada, 2001), hlm. 65. Bahkan bukan hanya itu, pendidikan dalam sepanjang sejarah acapkali bukan hanya sebagai upaya penyadaran murni terhadap masyarakat, tetapi, pendidikan juga dijadikan sebagai alat untuk kepentingan kekuasaan. Pendidikn yang dibangun demi dan hanya untuk menciptakan kelanggengan kekuasaan. Kerajaan-kerajaan Tarumanagara, Sriwijaya, dan Majapahit untuk menjaga kelanggengan dan keagungan negara teokrasi memompakan pendidikan-pendidikan akhlak dan 
bersifat formal dan hafalan, bukan pada pemaknaannya atau substansinya. Budaya hafalan ini bahkan masih terpelihara di sebagian besar lembaga pendidikan Islam di negara-negara Arab sebagai basis ilmuilmu keislaman. Akibatnya, sampai saat ini mereka (baca: para alumninya) masih menghadapi problem metodologi dalam pembelajaran agama Islam. Pola transformasi nilai di lembaga-lembaga pendidikan Islam, lebih mengedepankan nuansa fighiyah (Fiqh Oriented atau Figh Minded) yang berorietasi pada benar-salah, pahala-dosa. Demikan juga pada pengajaran yang bersifat informal, para ulama lebih menekankan metode "menakutnakuti" jamaahnya dengan berbagai dimensi siksa kubur dan pedihnya adzab api neraka. Setelah itu ummat "dimanjakan" dengan "iming-iming" pahala yang besar dengan segala hitungan dan kelipatannya. Proses pendidikan Agama Islam, terlalu berusaha untuk "mendramatisir" kelipatan pahala ibadah-ibadah ritual; ramadhan, berumrah pada bulan ramadhan, kelipatan pahala orang yang bersedeqah dan berzakat. Sehingga, peserta didik sedikit banyak dipengaruhi paradigma pahalaisme dan ketakutan yang semu. ${ }^{20}$

Sejatinya, ulama menduduki posisi penting dalam masyarakat Islam. Ulama tidak hanya sebagai figur ilmuan yang menguasai dan memahami ajaran-ajaran agama, tetapi juga sebagai penggerak, motivator dan dinamisator masyarakat ke arah pengembangan dan pembangunan umat. Perilaku ulama selalu menjadi teladan dan panutan. Ucapan ulama selalu menjadi pegangan dan pedoman. Ulama adalah pelita umat dan memiliki kharisma terhormat dalam masyarakat. Penerimaan atau penolakan masyarakat terhadap suatu gagasan, konsep atau program, banyak dipengaruhi oleh ulama.

Hal ini, sebagaimana yang disebutkan oleh Cak Nur bahwa ;

Tugas mulia lain daripada para ulama ialah menjaga akhlaq masyarakat. Pengetahuan dan pendalaman tentang ajaran agama yang dimilikinya memungkinkan para ulama bertindak selaku kekuatan moral. Dan jika

keagamaan di dalamnya. Lihat. Francis Wahono, Kapitalisme Pendidikan Antara Kompetisi dan Keadilan (Yogyakarta: Insist Press, 2001), hlm. 15

${ }^{20}$ Lihat Munir Mulkhan, Satu Tuhan Seribu Tafsir, (Yogyakarta : Kanisius, 2007) 
kita kaji dengan teliti ketentuan al-Qur'ân tentang mereka yang mendalami agama, kita dapatkan antara lain tugas mereka selaku pemberi peringatan kepada masyarakat agar mereka tetap bertaqwa kepada Allah dengan menjalankan perintah-perintah-Nya dan menjauhi larangan-larangan-Nya. Kesemuanya itu berujung kepada pelaksanaan budi pekerti luhur atau al-akhlaq al-karimah, kehidupan etis dan bermoral. ${ }^{21}$

Peran ulama bukan hanya pada aspek ibadah mahdhah, memberikan fatwa atau berdoa saja, tetapi juga mencakup berbagai bidang politik, ekonomi, sosial, budaya, pendidikan, dan sebagainya, sesuai dengan komprehensifitas ajaran Islam itu sendiri. Membatasi peran ulama pada persoalan agama, fatwa dan akhlak saja, merupakan kekeliruan besar, karena hal itu dipandang sebagai a historis, sebab dalam sejarah peran ulama sangat luas. Kualitas dan kapasitas keilmuan yang dimiliki para ulama telah mendorong mereka untuk aktif membimbing masyarakat dalam menjalani kehidupan sehari-hari. Modal keilmuan dan integritas diri menjadikan ulama sebagai tokoh sentral yang sampai saat ini paling bisa dipercaya. ${ }^{22}$

Sehingga tidak heran jika kemudian, Hiroko Horikoshi, berpendapat bahwa ulama mempunyai dua peran, yaitu memikirkan nasib rakyatnya, dan sebagai penanggung jawab dalam pengajaran ilmuilmu agama dan melestarikan praktek-praktek ortodoksi keagamaan para penganutnya. ${ }^{23}$ Peran yang terahir ini, agaknya menjadi problem

${ }^{21}$ Nurcholish Madjid, Kedudukan dan Peran Ulama Dalam Islam, Makalah untuk Klub Kajian Agama PARAMADINA Jakarta, 23 Mei 1997, h. 7

${ }^{22}$ Ulama pada awal sejarahnya, bukan saja terpisah dari khalifah, tetapi juga kadang tampil sebagai sosok pengontrol kekuasaan dan penjaga hati nurani umat, dan tidak jarang pula, pada kasus-kasus paling ekstrim, membuat hadirnya suatu kelompok oposisi, bila melihat praktik-praktik khalifah yang dipandang menyimpang. Ini bersamaan dengan kemerosotan kekuasaan yang bersumbu pada ikatan keagamaan menjadi ikatan kesukuan. lihat Aswab Mahasin, "Keterkaitan dan hubungan Umara dan Ulama dalam Islam”, dalam Budhy Munawwar Rahman (ed.), Kontekstualisasi Doktrin Islam dalam Sejarah, (Jakarta: Yayasan Paramadina, 1994), h. 606

23 Hiroko Horikoshi, Kyai dan Perubahan Sosial, (Jakarta : Perhimpunan Pengembangan Pesantren dan Masyarakat (P3M), 1983), h. 114 
tersendiri dalam sejarah ulama. Misalnya, penguatan terhadap semangat fanatisme bisa terjaga bahkan melembaga. Lebih-lebih lagi jika ulama kemudian berkerjasama dengan penguasa, untuk melegalkan semangat fanatisme tersebut. Kisah yang terjadi pada masa Abbasiyah, pada masa Al-Ma'mun yang memberlakukan kebijakan mihnah terhadap ulama yang tidak sehaluan dengan faham kemakhlukan Al-Qur'an yang dipegangi doktrin Mu'tazilah, ${ }^{24}$ menjadi bagian penting dari tesis Hiroko di atas. Di Indonesia lembaga fatwa MUI yang mengharamkan paham sekularisme, liberalisme, dan pluralisme, serta ahmadiyah juga menjadi contoh dari peran sentral ulama dalam kapasitasnya sebagai pelestari dari praktikpraktik keagamaan.

Banyak kasus-kasus lain yang menjadi kegagalam peran ulama. Hal ini yang menjadi kegelisahan Cak Nur, ketika melihat problem tersebut. Dalam hal ini, Cak Nur pernah menulis ;

\section{... Yang amat penting, dan hampir-hampir setara}

dengan suatu peringatan, ialah bahwa kelebihan ulama kepada orang awam terletak pada adanya ilmu mereka, bukan pada adanya wewenang suci, kekuasaan keruhanian atau keagamaan, semacam "otoritas ekslesiastik" (ecclesiastical authorithy). ${ }^{25}$

Kegelisahan Cak Nur tersebut, menjadi wajar jika kemudian ulama -dengan fatwanya- justru tidak memberikan dampak mashlahah bagi kepentingan manusia. Ini tentu sangat membahayakan bagi kelangsungan keberagamaan umat manusia. Karena sesungguhnya, ghayah maqsudah (tujuan puncak) dari sebuah pensyariatan hukum adalah untuk

${ }^{24}$ Ibn Hanbal, seorang ulama ortodok yang berpegang teguh kepada artiliteral ayat dan hadis, adalah diantara ulama yang terkena kebijakan mihnah ini, ia diadili dan dipaksa untuk meyakini bahwa Al-Qur'an itu makhluk, akan tetapi ia tetap berpegang teguh pada aqidahnya yang berkeyakinan bahwa Al-Qur'an itu kalam Allah dan Qadim. Akibatnya bisa di duga Ibn Hanbal disiksa dengan di cambuk dan dipenjarakan hingga penguasa berikutnya, mengganti Al-Ma'mun melepaskan Ibn Hanbal. lihat Richard W.Buliet, The Patricians of Nishapur, (Cambridge: Harvard University Press, 1972), h. 66

${ }^{25}$ Nurcholish Madjid, "Tentang Ulama dan Keulamaan dan Ketokohan K. H. Ali Yafie sebagai Cerin Keulamaan Sejati Masa Kini”, dalam K. H. Ali Yafie, Jati Diri Tempaan Fiqh, (Jakarta : FKMPASS, 2001), h. viii 
mewujudkan kemashlahatan manusia yang tercermin dari hikmah yang dikandungnya. ${ }^{26}$

\section{Persoalan Ilmu dalam Islam; Meneguhkan Makna Ulama}

Dalam al-Qur'an, kata ilm, dengan berbagai bentuknya terulang sampai 854 kali. ${ }^{27}$ Yang berarti kejelasan, karena ia berakar dari bentuk kata yang bercirikan kejelasan. ${ }^{28}$ Selain itu, kata $\mathrm{ilm}$, berasal dari kata dasar 'ain, lam, dan mim, yang terambil dari perkataan 'alamah, yang berarti tanda, petunjuk, atau indikasi yang dengannya sesuatu atau seseorang itu dikenal. Dengan demikian ma'lam, berarti "rambu-rambu jalan" atau "sesuatu yang dengannya seseorang membimbing dirinya atau sesuatu yang membimbing seseorang". Selaras dengan itu, 'a'lam juga bisa diartikan dengan "petunjuk jalan". ${ }^{29}$ Maka tidak heran jika kemudian, kata 'ayah (jamaknya : ayat), yang berarti tanda, selalu merujuk pada ayatayat al-Qur'an (qauliyah) dan fenomena alam (kauniyah).

Secara deskriptif, al-Qur'an sebenarnya telah memberikan gambaran bagaimana Allah memberikan pengetahuan pengetahuan kepada Adam, ketika para Malaikat tidak mampu menyebutkan "namanama" tersebut. Inilah sebenarnya esensi penciptaan manusia tersebut, yaitu untuk mempelajari alam semesta, hukum-hukum susunan batinnya, dan proses sejarah. Semua itu kemudian digunakan untuk "pengabdian kepada Tuhan". ${ }^{30}$ Hal inilah yang membuat manusia dihormati sebagai sebaik-baiknya makhluq dan bahkan Malaikat, kecuali Iblis, bersujud dihadapan Adam, sebagai simbol manusia.

Karakteristik yang membedakan antara manusia dengan makhluq lain adalah kapasitasnya dalam memberikan "nama-nama" kepada bendabenda. Memberi "nama" benda-benda mempertegas kapasitas manusia

${ }^{26}$ Yusuf Al-Qaradhawi, Fatawa Mu'ashirah, (Beirut : Dar al-Ma'rifah, 1988), h. 26

${ }^{27}$ M. Quraish Shihab. Wawasan al-Qur'an (Bandung : Mizan. 1999) hlm 234.

${ }^{28}$ Misalnya 'alam (bendera), 'ulmat (bibir sumbing), 'a'lam (gunung-gunung), 'alamat (alamat), dsb.

29 Wan Mohd Nor Wan Daud. Filsafat dan Praktik Pendidikan Islam Syed M. Naquib Al-Attas. (Bandung : Mizan. 2003) hlm 144.

${ }^{30}$ Fazlur Rahman. "The Qur'anic Consept of God” dalam Islamic Studies, Jilid VI, no. 1.1967 , hlm $8-11$. 
dalam menemukan sifat-sifat benda, hubungan timbal balik dan hukumhukum perilakunya. ${ }^{31}$ Ketika kita menamakan sesuatu itu batu, pohon, atau elektron, kita akan mengetahui bagaimana perilakunya, bisa mengetahui lebih banyak tentanya, bahkan bisa meramalkannya. Dengan kata lain, manusia berbeda dengan makhluq lainya adalah ketika ia mempunyai pengetahuan kreatif dan ilmiah mengenai benda-benda (ilmu eksakta), mengenai susunan batinnya (ilmu kejiwaaan), dan mengenai perilaku luar manusia sebagai suatu proses yang berjalan terus menerus dalam sebuah masa (ilmu kesejarahan).

Ketika kita tidak mampu berbicara tentang Tuhan kecuali dengan perumpamaan-perumpamaan, maka Tuhan berkomunikasi dengan manusia melalu "ayat". Disini manusia bertanggungjawab untuk mengungkapkan dan memahaminya. Untuk mengungkap realitas dibalik ayat tersebut (the ultimate reality), manusia harus menggunakan potensi akal pikirannya, dengan cara mengaitkan ketiga realitas diatas berdasarkan prinsip fundamental tentang kesatuan (unity) dan keseluruhan (totality). ${ }^{32}$

Ajakan untuk memahami relitas alam ini, sebenarnya sudah ada dalam al-Qur'an. Bahkan ayat pertama kali turun kepada Muhammad adalah "bacalah! Bacalah atas nama Tuhanmu apa-apa yang telah Dia ciptakan". ${ }^{33}$ Jadi, sejak pertama umat Islam telah ditantang untuk membawa teks, berupa alam raya. Alam raya sendiri artinya "tanda" yang menunjukkan kepada realitas diluarnya. ${ }^{34}$ Dalam sebuah syairnya, Hamka menyebutkan tentang hal ini;

Mekar mengembang, fajar menyingsing

Ombak berdebur, gunung menjulang, langit menghijau

31 Ibid.

32 Imam Chanafie Al-Jauhari. Hermeneutika Islam; Membangun Peradaban Tuhan di Pentas Global, (Yogyakarta : Ittaqa Press. 1999) hlm 53.

${ }^{33}$ QS. Al-Alaq : 1.

34 Komaruddin Hidayat, "Melampaui Nama-Nama Islam dan Postmodenisme" dalam edy A. Efendi (ed) Dekonstruksi Mazhab Ciputat. (Bandung : Zaman Wacana Mulia. 1999) hlm 96 


\section{Rimba belukar sunyi, awan berarak menepi}

Air mengalir, serasa terjun pimping dilereng dikecut angina

Anak menangis dalam pangkuan bundanya, ibu bernyanyi

Mengingat ayahnya

Keringat mengalir di dahi seorang yang baru pulang

Dari pekerjaannya dan anaknya berlari kehalaman

Menyanbutnya ayahnya pulang...........

Kemana saja ... Yang mana saja! Menengadah keatas

Atau menekur kebawah

Hanya satu yang tampak di mata, di hati : Allah!"

Hanya satu suara yang terdengar: "Allah!"

"Tuhanku, Tidaklah Engkau jadikan segalanya ini dengan sia-sia?"35

Penegasan serupa juga di ungkapkan oleh Ibn 'Arabi bahwa "Alam semesta adalah tempat tanda-tanda, dan setiap realitas adalah tanda yang membawa kepada realitas ketuhanan...." Ungkapan ini, menandaskan bahwa upaya memahami alam semesta, melalui proses refleksi dan berfikir akan menumbuhkan sikap keberagamaan dalam diri seseorang. Karena bagi Ibn 'Arabi benda-benda fisik di alam semesta ini, merupakan tanda-tanda dari sesuatu yang tidak tampak (non fisik), sebuah petunjuk realitas.

Selain itu, salah satu pemikiran Hamzah al-Fansuri yang menggambarkan manifestasi dan pencitraan Tuhan di Alam Semesta, tergambar dengan jelas, dalam salah satu tulisannya Asrâr al-'Ârifîn (Rahasia Kaum Gnostik), yaitu :

Ketahuilah olehmu hai thalib, .... sabda Nabi saw "man 'arafa nafsah, fa qad 'arafa rabbah", yakni barang siapa mengenal dirinya, makasanya mengenal Tuhannya; arti mengenal Tuhannya dan mengenal dirinya, yakni dirinya dan semesta sekalian dalam ilmu Allah, seperti biji dan sepohon; pohonnya dalam sebiji itu sungguhpun tiada kelihatan, tetapi hukumnya

${ }^{35}$ Hamka. Filsafat Ketuhanan. (Surabaya : Penerbit Karunia. 1985), hlm 113.

${ }^{36}$ Stephen Hirtenstein, Dari Keragaman ke Kesatuan Wujud; Ajaran dan Kehidupan Spritual Syaikh al-Akbar Ibn 'Arabi, (Jakarta: PT. RajaGrafindo Persada, 2001), hlm. 39. 
ada dalam biji itu .... "Maka demi Allah, sekaliannya Ia jua, tamsil seperti biji sebiji, dalamnya pohon kayu sepohon dengan selengkapnya, asalnya biji itu jua. Setelah menjadi kayu biji sebiji itu gaib, kayu jua kelihatannya; warnanya berbaga-bagai, rasanya berbagai-bagai, asalnya sebiji itu jua. ${ }^{37}$

Hamzah Fansuri seringkali mengungkapkan "Keindahan" Tuhan dengan menjadikan fenomena alam sebagai basis puitisnya. Misalnya ia menggunakan lambang-lambang laut. Katanya:

Dengarkan sini hai anak ratu

Ombak dan air asalnya Satu

Seperti manikam muhit dan batu

Inilah tamsil engkau dan ratu. ${ }^{38}$

Di sini Hamzah Fansuri, ingin mengatakan bahwa fenomena ombak (sebagai Makhluq) dan air (sebagai Tuhan) ; ombak asalnya dari air yang kekal, dan ombak akan kembali kepada air, yang melambangkan hubungan yang tidak boleh putus antara para makhluk dan Wujud serta Zat Tuhan. Akan tetapi, pemahaman ini, bukan berarti bahwa Zat Tuhan bersambung dengan zat makhluk sebagaimana zat ombak bersambung dengan zat air; sebab Hamzah telah menyatakan bahawa tidak ada yang menyamai Tuhan, sebab wujud makhluk adalah wujud mumkin, bukan wujud yang wajib al-wujud; yang wajib al-wujud hanya Tuhan.

Penghayatan yang begitu mendalam terhadap realitas alam raya, yang menjadi ayat-ayat atau tanda-tanda Tuhan, baik berupa Kitab Suci maupun alam semesta merupakan bagian amat sentral dalam penghayatan keagamaan bagi seorang ulama. Hal ini, juga yang menjadi catatan Cak Nur, terkait dengan ulama.

......yang tergolong para ulama ialah mereka yang memahami dengan penuh penghayatan gejala-gejala alam sekitarnya seperti hujan (meteorologi), tetumbuhan (flora), fenomena geologis

${ }^{37}$ Di kutip dari Taufik Abdullah, dkk., Ensiklopedi Tematis Islam Asia Tenggara, (Jakarta : Ichtiar Baru Van Hoeve, tt), hlm. 143.

${ }^{38}$ Dikutip dari Abdul Hadi WM, Tasawuf Yang Tertindas, Kajian Hermeneutik terhadap Karya-Karya Hamzah Fansuri”, (Jakarta : Paramadina, 2001), hlm. 386. 
gunung-gunung (mineralogi), gejala kemanusiaan (ilmu-ilmu sosial), dan binatang-binatang (fauna) dengan berbagai variasi dan kompleksitasnya. Mereka mempunyai potensi sebagai yang paling bertaqwa kepada Allah karena pemahaman dan penghayatan kepada gejala-gejala tersebut adalah juga berarti pemahaman dan penghayatan kepada ayat-ayat Allah, sebab seluruh langit dan bumi beserta segala isi dan kejadian di dalamnya adalah ayat-ayat atau tanda-tanda Allah. Dengan pemahaman dan penghayatan ayat-ayat itu tumbuh keinsyafan akan keagungan Allah dan kehadiran-Nya dalam hidup.... ${ }^{39}$

Seorang Ilmuan, semestinya tidak mendasarkan kegiatan ilmiahnya semata-mata bersifat kognitif dan skill an sich, melainkan kesemuanya dilakukan atas dasar niat dan motivasi intrinsiknya yang keluar dari hati nurani (conscience) yang paling dalam untuk memenuhi aturan-aturan Allah. Sehingga antara science dan con-science merupakan satu kesatuan dan totalitas yang bermuara pada jiwa rabbaniyyat. (QS. Ali Imran : 79). Ketika mengembangkan dan menggali konsep teoritis dan praksis, semestinya tidak hanya berhenti pada the fact tetapi juga the fact behind the fact, pada saat mengemukakan makna ruhani atau metafisika pada setiap pernyataan fisika.

Prinsip ini, tidak memisahkan ilmu pengetahuan dengan nilainilai moral religius. Antara ilmu dan etika, kesemuanya adalah satu kesatuan mutlak. Ilmu dan aktivitas keilmuan merupkan manifestasi dari pengabdian manusia kepada Tuhan. Tidak ada batas antara ilmu dan amal, tidak ada hijab antara ilmu dengan iman. Implikasinya, seorang berilmu pengetahuan memiliki komitmen terhadap Tuhannya, sekaligus menerima sepenuh hati hukum moral yang diberikan-Nya. ${ }^{40}$ Sehingga ia tumbuh sebagai insan yang mencintai perdamaian, dapat hidup selaras, stabil dan berbudi, yakin sepenuhnya akan kemurahan Tuhan yang tidak terbatas, keadilan-Nya yang tidak ada tandingannya, dan hidup dalam harmoni dengan alam.

${ }^{39}$ Nurcholish Madjid, Kedudukan dan Peran Ulama Dalam Islam, h. 2

${ }^{40}$ Ali Ashraf, Horison Baru Pendidikan Islam, (Jakarta : Pustaka Firdaus. 1996) hlm $23-24$. 
Dengan demikian, selain makhluq rasional, manusia adalah makhluq spritual, yang mengapresiasikan "titah" Tuhan sebagai khalifah fil ardl, yang memiliki kekuasaan tidak terbatas untuk mengontrol dan mengatur alam semesta berdasarkan otoritas Tuhan, yang mampu menghadirkan Tuhan dalam kesadarannya disetiap saat, dalam ketakjuban pada keindahan, kedahsyatan dan keharmonisan alam semesta, yang mendasarkan setiap aktivitasnya pada sinaran "nama-nama" Tuhan. Pemahaman interelasi antara Tuhan, manusia, dan alam semesta, menjadi sebuah kesadaran mutlak bagi seorang ulama dalam mengembangkan keagamanaanya.

Prinsip ini mirip dengan sebutan Chalen E. Westate sebagai "Spritual Welness", yang diartikan sebagai suatu perwujudan pribadi yang tercermin dalam keterbukaan terhadap dimensi kehidupan lainnya. ${ }^{41}$ Selanjutnya ia mengemukakan bahwa ada empat dimensi "Spritual Welness" ini, (1), Meaning of Life, yaitu berkemampuan untuk mewujudkan dirinya secara bermakna dalam setiap dimensi hidup secara terpadu dan utuh. (2), Intrinsik Value, yaitu memiliki nilai-nilai intrinsik sebagai perpaduan berprilaku. (3) Trancendence, yakni berkemampuan untuk mentransendensikan atau melakukan hubungan dengan dimensi yang lebih luas dan luhur. Dan (4), Community of Shared Values and Support, adalah berkemampuan dalam melakukan hubungan kemasyarakatan dengan dukungan nilai-nilai bersama.

\section{Penutup}

Ulama semestinya memiliki visi pencerahan (enlighment), membebaskan ummat dari keterbelengguan (kejumudan) berfikir luas, optimisme dan paradigma etos kerja. Namun kebanyakan ulama lebih mengedepankan paradigma Fiqhiyah, yaitu kelipatan pahala dan sejenisnya, pahala sholat mana yang lebih besar atau ibadah mana yang lebih banyak "memproduksi pahala." Kondisi ini menjadikan ummat

41 Dikutip dari Muhammad Surya, "Integrasi Tauhid Ilmu dalam Sistem Pendidikan Nasional" dalam Tauhid Ilmu dan Implementasinya dalam Pendidikan. (Bandung : Nuansa. 2000) hlm $84-85$. 
menjalankan agama pada bentuk fiqhnya saja. Padahal prilaku terbentuk dari hasil pemahaman terhadap nilai ketauhidan, keyakinan terhadap "sesuatu" yang serba "Maha".

Saat seorang ayah bangga terhadap anaknya yang hafal dan lancar membaca doa makan hanya dalam bentuk formal bacaan, anak tidak diberikan pemahaman pada siapa pemberi rezki makanan yang sedang disantapnya. Saat orang tua bangga anaknya hafal doa tidur, tanpa dibarengi pemberian pemahaman sikap kepasrahan terhadap kekuasaan Allah SWT yang dapat menghidupkan dan mencabut nyawa kita setiap saat. Saat anaknya disuruh bersedekah hanya difahamkan bahwa pahala yang didapatkan akan berlipat ganda, bukan pada pemahaman bahwa sesungguhnya uang yang kita punya pada hakikatnya bukan milik kita. Akumulasi dari sistem ini terciptalah generasi yang materialistis, sombong, angkuh. Sebab sesungguhnya sikap dermawan, tidak sombong hanya bisa ditanamkan dengan pemahaman yang utuh terhadap ketauhidan bahwa hanya Allahlah yang maha kaya dan berkuasa atas tiap sesuatu.

Kondisi dan sikap peserta didik ini, didukung oleh fakta atau fenomena yang cenderung kepada krisis moral atau akhlaq; terjadinya tawuran siswa antar sekolah, hubungan seks diluar nikah, dan seterusnya. Hal ini, disebabkan oleh model pembelajaran agama Islam yang tidak menonjolkan pada penanaman rasa cinta dan kasih sayang, toleransi, respectasi, dan lainnya. Wallahu a'lam bi showab

\section{DAFTAR PUSTAKA}

Abdul Hadi WM, Tasawuf Yang Tertindas, Kajian Hermeneutik terhadap Karya-Karya Hamzah Fansuri”, (Jakarta : Paramadina, 2001)

Ahmad Fatoni, "Mendongkrak Pamor Pendidikan Islam" Sriwijaya Pos, Rabu, 05 Mei 2004. 
Ali Ashraf, Horison Baru Pendidikan Islam, (Jakarta : Pustaka Firdaus. 1996)

Al-Maraghi, Tafsir Al-Maraghi, Jilid VIII, (Beirut : Dar al-Fikr, 1974)

Azyumardi Azra, Jaringan Intelektual Ulama Nusantara, (Bandung: Mizan, 1994).

Budhy Munawwar Rahman (ed.), Kontekstualisasi Doktrin Islam dalam Sejarah, (Jakarta: Yayasan Paramadina, 1994)

Argumen Islam untuk Sekularisme; Islam

Progresif dan Perkembangan Diskursusnya, (Jakarta : Grasindo, 2010).

Membaca Nurcholish Madjid Islam dan Pluralisme, Edisi Digital, (Jakarta : Democracy Project, 2011)

Fazlur Rahman. "The Qur'anic Consept of God" dalam Islamic Studies, Jilid VI, no. 1. 1967,

Francis Wahono, Kapitalisme Pendidikan Antara Kompetisi dan Keadilan (Yogyakarta: Insist Press, 2001)

Hamka. Filsafat Ketuhanan. (Surabaya : Penerbit Karunia. 1985)

Harun Nasotion, Islam Rasional : Gagasan dan Pemikiran, (Cet. V; Bandung: Mizan, 1998)

Hiroko Horikoshi, Kyai dan Perubahan Sosial, (Jakarta : Perhimpunan Pengembangan Pesantren dan Masyarakat (P3M), 1983)

Imam Chanafie Al-Jauhari. Hermeneutika Islam; Membangun Peradaban Tuhan di Pentas Global, (Yogyakarta : Ittaqa Press. 1999)

Jalaluddin, Teologi Pendidikan, (Jakarta: PT. Raja Grafindo Persada, 2001)

Juhaya S. Praja, Aliran-Aliran Filsafat dan Etika, (Cet. I; Bogor: Kencana, 2003)

Komaruddin Hidayat, "Melampaui Nama-Nama Islam dan Postmodenisme" dalam edy A. Efendi (ed) Dekonstruksi Mazhab Ciputat. (Bandung : Zaman Wacana Mulia. 1999) 
Mahmud Yunus, Kamus Arab-Indonesia, (Jakarta : Yayasan Penyelenggara Penerjemah Penafsir Al-Qur;an, 1973)

Manfred Ziemek dalam bukunya, Pesantren dalam Perubahan Sosial, (Jakarta: P3M, 1986)

Muhammad Surya, "Integrasi Tauhid Ilmu dalam Sistem Pendidikan Nasional" dalam Tauhi Ilmu dan Implementasinya dalam Pendidikan. (Bandung : Nuansa. 2000)

Munir Mulkhan, Satu Tuhan Seribu Tafsir, (Yogyakarta : Kanisius, 2007)

Mona Abaza, Indonesian Students in Cairo, (Paris: EHESS, 1994).

M. Dawam Rahardjo, Ensiklopedi al-Qur'an, (Jakarta : Paramadina, 1996)

M. Dawam Rahardjo, Intelektual Integensia dan Perilaku Politik Bangsa Risalah Cendikiawan Muslim, (Bandung : Mizan, 1993)

M. Atho Mudzhar, "In the Making of Islamic Studies in Indonesia (In Search for a Qiblah)," makalah disampaikan dalam seminar internasional Islam in Indonesia: Intellectualization and Social Transformation, di Jakarta 23-24 November 2000

M. Quraish Shihab. Wawasan al-Qur'an (Bandung : Mizan. 1999) hlm 234.

Nurcholish Madjid, "Tentang Ulama dan Keulamaan dan Ketokohan K. H. Ali Yafie sebagai Cerin Keulamaan Sejati Masa Kini”, dalam K. H. Ali Yafie, Jati Diri Tempaan Fiqh, (Jakarta : FKMPASS, 2001), h. viii

, Kedudukan dan Peran Ulama Dalam Islam, Makalah untuk Klub Kajian Agama PARAMADINA Jakarta, 23 Mei 1997,

"Pendidikan, Langkah Strategis Mempersiapkan SDM Berkualitas" dalam Indra Djati, Menuju Masyarakat Belajar Menggagas Paradigma Pendidikan, (Jakarta: Paramadina, 2001)

Richard W.Buliet, The Patricians of Nishapur, (Cambridge: Harvard University Press, 1972) 
Sayyid Qutb. Fi Dzilalil Qur'an, (Beirut : Ihyan al-Turats al-Arabi, 1967).

Stephen Hirtenstein, Dari Keragaman ke Kesatuan Wujud ; Ajaran dan Kehidupan Spritual Syaikh al-Akbar Ibn 'Arabi, (Jakarta : PT. RajaGrafindo Persada, 2001)

Taufik Abdullah, dkk., Ensiklopedi Tematis Islam Asia Tenggara, (Jakarta : Ichtiar Baru Van Hoeve, $t \mathrm{t}$ )

Wan Mohd Nor Wan Daud. Filsafat dan Praktik Pendidikan Islam Syed M. Naquib Al-Attas. (Bandung : Mizan. 2003)

Yusuf Al-Qaradhawi, Fatawa Mu'ashirah, (Beirut : Dar al-Ma'rifah, 1988)

Zamakhsyari Dhofier, Tradisi Pesantren, (Jakarta : LP3ES, 1985)

Imam Hanafi, MA adalah Peneliti di Intitute for Souteast Asian Islamic Studies (ISAIS) Universitas Islam Negeri Sultan Syarif Kasim Riau. E-mail: imam.hanafi@uin-suska.ac.id

Dr. Sofiandi adalah Dosen tetap pada STIT Ar-Risalah Guntung Kabupaten Indragiri Hilir. Email: sofiandi88@gmail.com 